Zabytkoznawstwo i Konserwatorstwo XIII, Torun 2011

\title{
Wspomnienie o Profesor Marii Roznerskiej
}

W Wwwietniu 2011 roku minęła dziesiąa rocznica śmierci Profesor doktor Maril Roznerskiej. Śmierci nagłej i niespodziewanej nie tylko dla Jej najbliższych, ale również dla osób związanych z Nią zawodowo, w tym pracowników Zakładu Konserwacji Malarstwa i Rzeźby Polichromowanej UMK, którym kierowała od 1979 roku. Byłem uczniem Pani Profesor, a przez lata Jej bliskim asystentem, co szczególnie skłania mnie do napisania tych kilku słów przypominających Jej postać.

Profesor Maria Roznerska urodziła się w Czersku 24 maja 1934 roku. Studia z konserwacji dzieł sztuki ukończyła na Wydziale Sztuk Pięknych Uniwersytetu Mikołaja Kopernika w Toruniu w 1956 roku i rozpoczęła wówczas pracę jako asystent w Katedrze Technologii i Technik Malarskich. Rozprawę doktorską obroniła w 1967 roku w Instytucie Historii Kultury Materialnej PAN w Warszawie, a przewód kwalifikacyjny II stopnia przeprowadziła w 1979 roku na Akademii Sztuk Pięknych w Krakowie. W 1990 roku uzyskała tytuł profesora nadzwyczajnego, w roku 1995 zaś tytuł profesora zwyczajnego. Od początku swej drogi naukowej do końca życia była związana z Instytutem Zabytkoznawstwa i Konserwatorstwa Wydziału Sztuk Pięknych UMK.

Profesor Roznerska była czynnym konserwatorem zabytków, wybitnym fachowcem, nauczycielem akademickim, wychowawca wielu pokoleń konserwatorów reprezentujących tak zwaną toruńską szkołę konserwacji. Pamiętam Ja jako osobę o niezwykłej kulturze, zawsze przyjazną ludziom. Szanowaliśmy Ja jako szefa, który doceniał swoich podwładnych i zawsze szczerze im pomagał. Nigdy nie czuliśmy się przez Nią kontrolowani, obdarzała nas, swoich pracowników, dużym zaufaniem, a my tego zaufania nigdy nie nadużywaliśmy. Była osobowością wśród konserwatorów, mają- 
ca niezwykły dar zjednywania sobie ludzi, studentom potrafiła wybaczyć wszystko. Pamiętam, jak dopingowała nas, młodych wówczas pracowników, do rozwijania zainteresowań badawczych i wspinania się po szczeblach kariery naukowej. Pamiętam do dziś ogromny żal i smutek na wieść o Jej śmierci; pamiętam dzień pogrzebu, tłumy zgromadzone w kościele na mszy i na cmentarzu. I przypominam sobie pogodę w tym dniu, brzydką i deszczową. Była to już wiosna, ale wyjątkowo tego roku opóźniona. Pamiętam też słowa wtedy wypowiedziane, że już nigdy nie będzie tak, jak było. I dziś, po latach, ta myśl jest wciąż aktualna. Rzeczywiście, droga Pani Profesor, tamte czasy już nigdy nie powróca, a szkoda.

Dariusz Markowski 